\title{
Financial Markets, External Shocks and Policy Responses: The Case of Brazil 2001*
}

\author{
Mercados financeiros, choques externos $e$ \\ respostas a politicas: o caso do Brasil 2001
}

LAURO VIEIRA DE FARIA*

\begin{abstract}
RESUMO: Este artigo avalia a resposta macroeconômica do governo brasileiro em 2001, após o surgimento de fortes eventos negativos nos setores externo e interno, com foco particular nas políticas monetária e cambial. Ele aponta que o tipo de reação macroeconômica representada pelo modelo padrão de Mundell-Fleming é de pouca importância prática em uma pequena economia aberta, englobada em dívidas denominadas em dólar e passando por uma crise de confiança como a do Brasil. A economia brasileira opera como se houvesse algum tipo de teto para a taxa de câmbio e para as taxas de juros, em um claro afastamento das premissas incorporadas no modelo "puro". Nesse tipo de ambiente, é necessário outro conjunto de ações para combater uma taxa de câmbio perigosa, o que é comprovado pelos eventos de 2001. Embora as ações tomadas pelas autoridades monetárias tenham se mostrado bem sucedidas naquele momento, o artigo mostra que elas vieram com um considerável custos financeiros. Portanto, o artigo argumenta a favor de outro conjunto de respostas macroeconômicas que deveria ter sido preferido para evitar tais custos.

PALAVRAS-CHAVE: Política monetária; taxa de câmbio; ultrapassagem; intervenção.
\end{abstract}

ABSTRACT: This paper evaluates the macroeconomic response of the Brazilian government in 2001 following the emergence of sharp negative events in both the external and internal sectors with particular focus on monetary and exchange rate policies. It points out that the kind of macroeconomic reaction depicted by the standard Mundell-Fleming model is of little practical importance in a small open economy engulfed in dollar denominated debts and experiencing a confidence crisis like Brazil's. The Brazilian economy operates as if there were some sorts of ceilings for the exchange rate and for interest rates, in a clear departure from the assumptions embodied in the "pure" model. In this kind of environment another set of actions is required to fight a dangerous exchange rate overshooting and that is proven by the events of 2001. Whilst the actions taken by the monetary authorities proved success-

\footnotetext{
* I thank the thoughtful remarks given by two anonymous referees.

** Economista e Consultor de Empresas. E-mail: laurovf@terra.com.br.
} 
ful at that moment the paper shows that they came with sizeable real and financial costs as collateral. Therefore, the paper argues in favour of another set of macroeconomic responses which should have been preferred if we were to avoid such costs.

KEYWORDS: Monetary policy; exchange rate; overshooting; intervention.

JEL Classification: E58.

\section{INTRODUCTION}

In the end of 2000, the outlook for the Brazilian economy seemed great. Industrial output was increasing at $7 \%$, short-term interest rates fell to $15 \%$, the exchange rate appeared to be stabilised at $\mathrm{R} \$ 2.00$ per dollar, inflation was within the central bank targeted range and another year of economic growth at $4.5 \%$ seemed probable. Nevertheless, a number of financial and real sector shocks, internal and external, turned this outlook upside down. We now feel happy with meagre results: GDP growth of only $1.7 \%$, short-term interest rate of $19 \%$ and the exchange rate at $\mathrm{R} \$ 2.50$ (Chart 1 ).

Difficulties abroad started in January 2001 when the US economic downturn became evident and the Fed rushed to cut its overnight interest rate. Difficulties proceeded in February, thanks to Turkey and its loss making banking system coupled with an overvalued exchange rate sustained by high interest rates. Turkey had minor effects on Brazil for obvious reasons but difficulties attained unforeseen heights from March on, due to the situation of Argentina. This country is enduring its third year recession. The combination of lax budgetary policies with a rigid currency regime sent it to a protracted deadlock. Brazil could not avoid the damage as our main partner in Latin America was so badly hit. Besides, as far as public debt and foreign obligations are concerned, Brazil has similar worrying conditions as Argentina. The vicious cycle ended with the sorry events of New York, which highlighted that recession is haunting the globe.

Domestically, we also had our share of problems. After eight years of reforms that shook the country's social structure and conveyed no better income growth performance, it was natural to assume that a significant part of the population would demand a major political change in the 2002 presidential election. The demand for change seemed evident. The most important candidate of the left was well ahead the others in the polls while the right-centre coalition that has ruled Brazil since 1995 struggled to stay afloat. Nevertheless, both shared the lack of transparency on the issues of the future monetary, exchange rate and fiscal regimes. Finally, since the midst of 2001, the Brazilian economy had to absorb the stagflation impact of a severe electric energy shortage. It was caused by under-investment in power plants aggravated by an unexpected drought. In the second half of the year, Brazilians in the South-eastern and North-eastern regions must save $20 \%$ of energy if compared to their consumption in the same period of 2000. 


\begin{tabular}{l|cc|cc}
\hline & \multicolumn{2}{|c|}{2001} & \multicolumn{2}{c}{2002} \\
\cline { 2 - 5 } & $\begin{array}{c}\text { market } \\
\text { Dec. 2000 }\end{array}$ & $\begin{array}{c}\text { IPEA } \\
\text { Nov. 2000 }\end{array}$ & $\begin{array}{c}\text { market } \\
\text { Dec. 2000 }\end{array}$ & $\begin{array}{c}\text { IPEA } \\
\text { Nov. 2000 }\end{array}$ \\
\hline Inflation (IGP-DI; \%) & 5.5 & 10.6 & 4.2 & 5.8 \\
GDP Growth (\%) & 4.0 & 1.7 & 4.5 & 2.3 \\
Selic Interest Rate* (\%) & 14.7 & 17.4 & 12.9 & 18.4 \\
Exchange rate** (R\$/US\$) & 2.01 & 2.65 & 2.09 & 2.63 \\
Primary Budget Surplus (\% of GDP) & 3.0 & 3.5 & 2.4 & 3.0 \\
Net Public Debt (\% of GDP) & na & 56.7 & na & 58.9 \\
Trade Balance (US\$ billion) & $(0.4)$ & 1.5 & 0.5 & 5.3 \\
Current Account (US\$ billion) & 27.1 & 24.8 & 28.0 & 21.2 \\
\hline
\end{tabular}

Notes: na = non available; $\left({ }^{*}\right)$ average; $\left({ }^{*}\right)$ end of period.

Sources: "Conjuntura Econômica," FGV, Jan. 2001; IPEA - Boletim de Conjuntura 55.

This paper discusses Brazil's macroeconomic response in 2001 following the emergence of those negative events in the external and internal sectors with particular focus on monetary and exchange rate policies. It is divided in four sections: (1) Introduction, (2) The Mundell-Fleming Model and the Brazilian Experience, (3) Inconsistencies of the Macroeconomic Regime and its Challenges, and (4) Conclusions.

\section{THE MUNDELL-FLEMING MODEL AND THE BRAZILIAN EXPERIENCE}

It has been well publicised that Brazil has a flexible exchange rate regime coupled with an inflation targeting framework. In this kind of environment what should be the policy responses to financial shocks stemming from the international economy? Let's begin with the simple answers provided by the standard Mundell-Fleming model for small open economies operating with flexible exchange rates and facing high levels of international capital mobility. The primary consequences of those shocks are increases in the expected exchange rate (currency depreciation) and/or in the risk premium affecting most types of the country's debt. The ensuing capital flight brought about by the divergence between expected rates of return in assets denominated in dollars and in the national currency is fully absorbed in the foreign exchange market by a devaluation of the spot exchange rate. International reserves are kept constant and so is the real money stock. The depreciation of the currency expands net exports, the result of which being a corresponding increase in real GDP. Interest rates also increase to balance the growth in money demand. The policy response of the government in this case is straightforward: let the foreign exchange market clear, follow suit the market in the process 
of setting the policy-related interest rate and, for the rest, wait for the good crop on economic activity.

Clearly, this is not a clear picture of the reality in a country like Brazil. Interest rates have gone up and so have the price of the dollar but the impact on output has been more contractionary than expansionary. The very real fact is that the working of a small open economy like Brazil's is far different from the story depicted by the standard Mundell-Fleming model. For three main reasons.

First, a neutral monetary policy cannot be assumed to hold in our case. In other words, the real money stock cannot be assumed to stay constant. To the contrary, given our history of hyperinflation and indexation, the Central Bank is forced to tighten the monetary policy because exchange rate depreciation can be detrimental to the achievement of the inflation target at least in the short and medium-terms. Another reason for monetary tightening is that the Central Bank needs to build a credible reputation as an inflation fighter in the context of our new monetary regime. Therefore, the real money supply is more likely to fall rather than stay the same. We have seen this recently in Brazil: between September and March 2001 the real money stock (M1), seasonally adjusted, fell by an annualised rate of $3.8 \%$ while in 2000 , it increased by $8.6 \%$.

Secondly, countries like Brazil issue a non-convertible currency, which implies that the most important entities - governments and firms - have their balance sheets mismatched not only in terms of different maturities but also in terms of different currencies. Typically, they have their assets mostly held in local money and important part of their liabilities denominated in foreign currency. Therefore, the net impact of a process of exchange rate depreciation on the level of economic activity is uncertain: net exports are stimulated but investment expenditures may be hurt as firms and the public sector suffer heavy capital losses because of their dollar denominated debts. For instance, at the end of 2001, it was estimated that around $50 \%$ of the net public debt are either indexed to the dollar or floated abroad in dollars. Brazilian net external liabilities summed US\$ 336 billion or 5.7 times the export receipts.

Thirdly, a straightforward policy response to financial shocks is further jeopardised in the Brazilian case because of the size and structure of the public debt. Net public debt reached 54\% of GDP in August 2001, a high figure even for developed countries not to mention emerging countries, that are prone to financial distress from time to time. Moreover, $51 \%$ of the internal debt in bonds and bills was indexed to the policy-related overnight interest rate (Selic rate). Investors have also got used to extract high real interest rates from those debt instruments. The real $^{1}$ Selic rate of the period $1999-2001$ has averaged $12.1 \%$ per year, a figure lower than the corresponding average rate of the fixed exchange rate period, of $22.1 \%$, but still very high with regard to the country's growth rate and international standards.

\footnotetext{
${ }^{1}$ Using the INPC as deflator.
} 
Therefore, Central Bank autonomy in the process of setting its key interest rate is more theoretical than real. A sharp increase in interest rates to fight an undesirable inflationary trend or a process of exchange rate overshooting may be counterproductive. A substantial part of the public debt is immediately raised which can spread alarm on investors about the government's capacity to fulfil its financial obligations. Moreover, the net impact of interest rate hikes on aggregate demand in an environment where the bulk of bonds and bills has very small duration is uncertain. The demand for investment is reduced but bondholders enjoy a wealth effect, presumably with positive impact on consumption. In other words, a tight monetary policy may result in an expansionary fiscal policy.

The consequences are simple. The Brazilian economy operates as if there were some sort of ceilings for the exchange rate and for interest rates, in a clear departure from the "pure" flexible exchange rate regime. True, the Selic interest rate went up from $15 \%$ to $19 \%$ per year between March and August 2001 and has stayed at this point since then. Yes, the exchange rate has depreciated by $38 \%$ in the same period. But throughout most of the year these were not equilibrium values or otherwise forward premiums on those variables would not have been so large and the Central Bank would not have had to intervene heavily in the foreign exchange market in order to sell "hedge" to external debtors. And the government also would not have had to negotiate another IMF package of 15 billion dollars to build a blanket of liquidity from August 2001 until the end of 2002.

Unable to allow those key variables - the exchange rate and the interest rate - to change freely in response to market forces, the Central Bank had to fill the gap of the excess demand for dollars by calling for changes in quantities rather than in prices. The first candidate to do so was sterilised foreign exchange interventions by the sales of dollar indexed bonds and reserves; the second was IMF support when the situation appeared troublesome, particularly after the news of energy shortage. Of course, this policy of "filling the gap" can not last forever. International reserves may fall to zero, IMF support may not come and the sale of dollar indexed bonds can become extremely dear as investors realise the potential of default stemmed from massive dollarised debts without the proper collateral. The hope for the authorities was that, in the meantime, exchange rate overshooting became evident and market expectations started to recede. In that case, ceilings could become equilibrium values and foreign exchange interventions could be reduced to the minimum needed in "normal" dirty floating regimes. Following the nice representation given by Dr. E. Borensztein, a symmetrical response within this package is equivalent to a point like $\mathrm{A}$ in the diagram below ${ }^{2}$.

\footnotetext{
${ }^{2}$ See Borensztein (2001). For a more rigorous representation, see Appendix.
} 


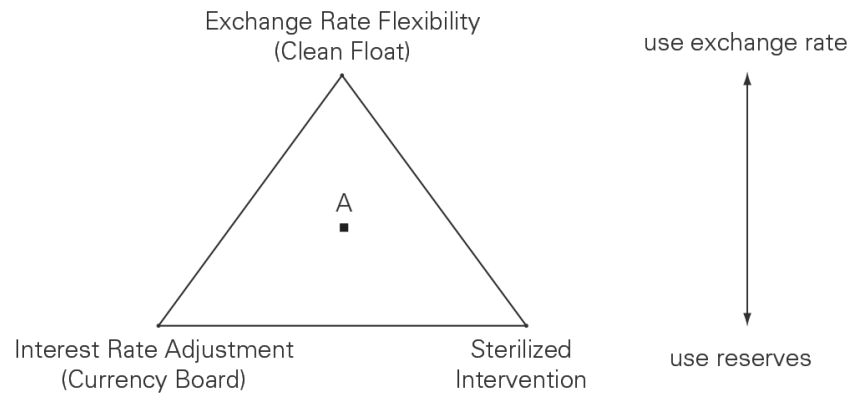

Less Sterilization

More Sterilization

Although not symmetrical, the response of the Central Bank throughout the year 2001 fell within this framework. Therefore, we have to recognise its basic correctness to cope with the shocks that slashed our economy in 2001. Interest rates were brought up but not as much as it would have been required if the government had to defend a fixed exchange rate. The inflation target was missed but nobody cared too much for that, given the extreme difficulties faced by the government in the management of the crisis. As for the exchange rate, after depreciating by almost $50 \%$ since December 2000, reaching R\$ 2.83 per dollar in October 2001, it tumbled (appreciated) to $\mathrm{R} \$ 2.36$ per dollar in December 2001. Foreign exchange interventions were huge throughout the year but the renewed stability in the financial markets allowed the Central Bank to lower them after October 2001. Quite a success but open to criticism as well and for good reasons.

First, side effects. Negative side effects are clear with regard to interest rate policy. During most of the year, the Central Bank was deliberately "late" in the interest rate curve, in other words, it did not follow market expectations of higher interest rates in the setting of the Selic overnight rate (Graph 1). That had the following consequences: the outstanding volume of pre-fixed interest rate bonds and bills shrank by $25.7 \%$ between September and February 2001 as the central bank refused to accept investors demands of higher interest rates on these instruments. The monetary authority resorted to sales of bonds indexed to the overnight interest rate, which increased their outstanding amount by $9.3 \%$ in the same period. The divergence between short-term interest rates and the Selic rate probably fuelled currency speculation as big investors and banks were able to finance their purchase of prefixed bonds and bills by borrowing from the central bank at this smaller overnight rate. No wonder that, in September 2001, the share of pre-fixed bonds was reduced to $9.1 \%$ of the total amount, that of overnight indexed bonds stayed at roughly $50 \%$ and the share of dollar indexed bonds increased to $31.4 \%$ (Graph 2 ). Since December 2000, the outstanding amount of federal securities in the hands of the public has increased by $14.6 \%$ in real terms. In the end, that policy paid since September 2001, short-term interest rates embodied in futures contracts have started to converge to the Selic rate — but the damage was already done. 
Clearly, these are not positive developments. Increasing the Central Bank focus on inflation targets requires appropriate flexibility in the management of interest rates. This flexibility is worsened in an environment where most of the public debt in bonds and bills is linked to the overnight interest rate. Moreover, interest rate focus was further undermined by the decrease in bank liquidity due to the imposition of $10 \%$ compulsory reserve requirements on time deposits in the midst of the year alongside with the established $45 \%$ on sight deposits. If past experience is a good advisor, a rapid reversal of these trends is highly doubtful.
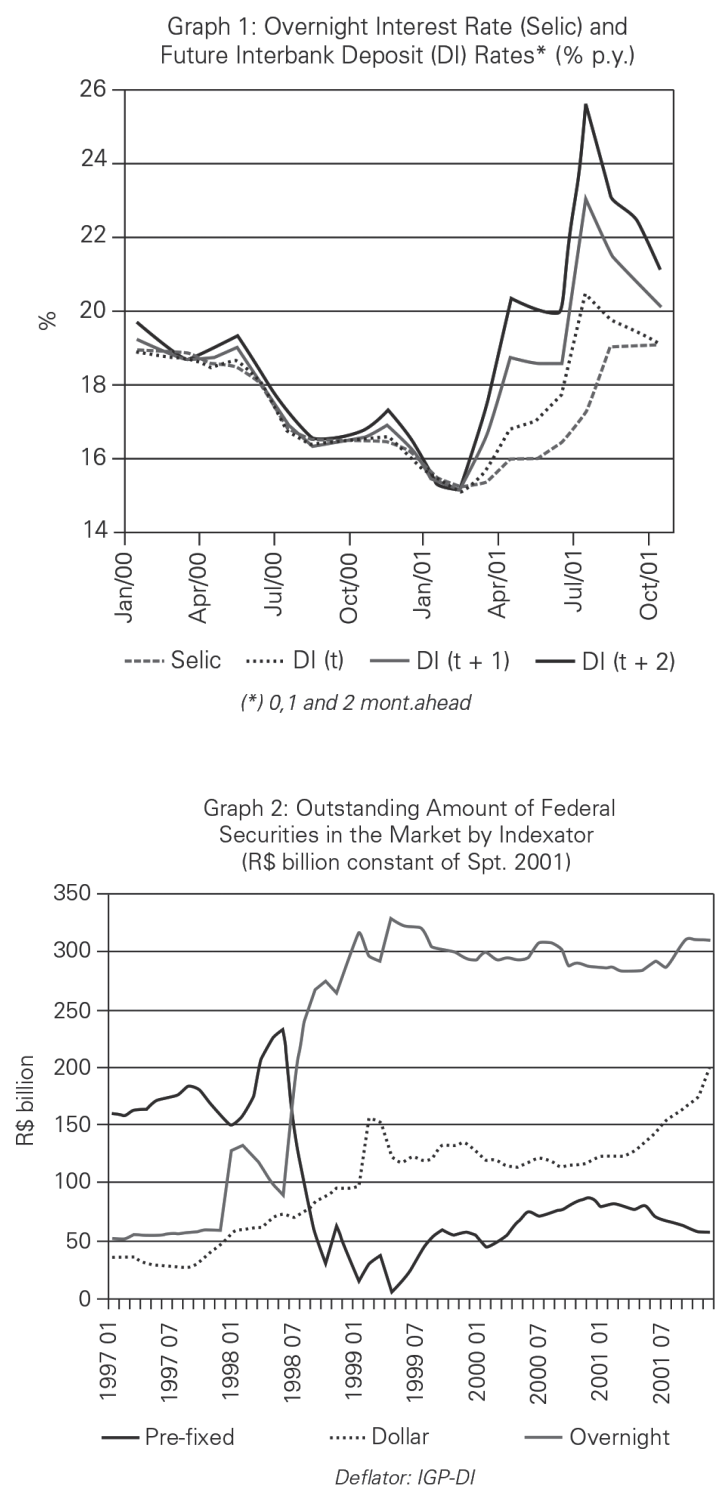
Let's turn now to the exchange rate policy, where lied the bulk of dissent among experts. The present regime, by its own nature, is more volatile than the former and, hence, potentially harmful to trade and to the generation of income. Periodic Central Bank interventions by trading foreign currencies and dollar denominated bonds are natural in order to prevent the occurrence of unexpected fluctuations. However, in Brazil, such interventions have been massive. The main reason is the impact on budgets stemming from the large stock of dollarised obligations (debt and capital) of both public and private sectors. Of course, by doing so, authorities lower the effectiveness of the exchange rate as a means of reaching an adequate balance between demand and supply. More importantly, by increasing its exposure in dollar denominated debts the government risks to corner itself till a point where further issues of debts become difficult, the call of the principal a reality and the currency is ready for another free fall. Moreover, hedging transactions and stabilised speculation done by the private sector will never develop fully if investors get used to the Central Bank as the sole seller of hedge during crisis episodes. Since 1999, the pervasive "dirtiness" of the exchange rate regime has been successful in order to cope with exchange rate crisis but this structural weakness has increased over time. Therefore, Brazilian authorities must take measures to improve the liquidity and competitive conditions of the foreign exchange market and reduce the stock of dollar-indexed bonds in order to allow a higher degree of exchange rate flexibility. The former can be foster by giving the market more freedom to clear whilst restricting by regulation the monopoly powers of bigger players and the latter by increasing the sale of federal bonds with monetary correction clauses instead of dollar denominated liabilities.

Thus, I think it is arguable to say that less reliability on foreign exchange rate interventions and more reliability on interest rate and exchange rate flexibility could have done better for the Brazilian economy in 2001. In terms of Mr. Borensztein's triangle, instead of a policy response closer to point B, as the government actually did, I wonder if better results could have been achieved with a policy response closer to a point like C (Figure 2).

Figure 2

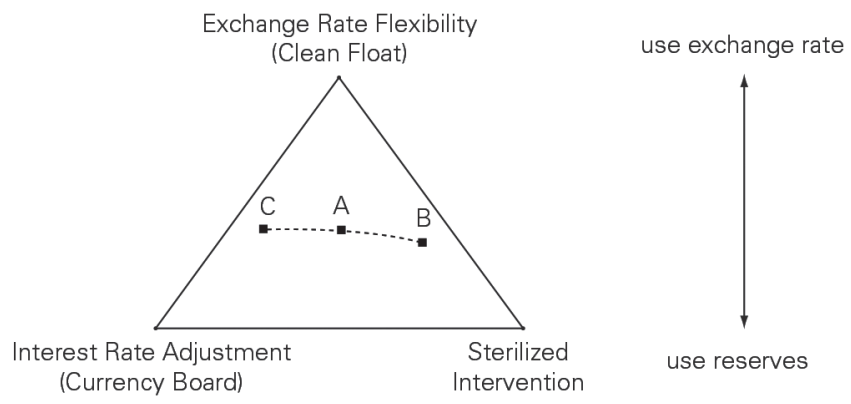


Secondly, as far as economic policy is concerned, the bottom line is economic growth and employment. We must not allow ourselves to be trapped into the situation depicted by the medical report joke: "operation successful, patient dead". Real GDP growth posted at only $1.5 \%$ in 2001 and is expected to reach the same figure in 2002. These results mean that the annual average economic growth in $1995-2002$ is going to be a mere $2.3 \%$, roughly the same as in the eighties, period known as the "lost decade" (Chart 2). In a country with huge social problems that got used to "historic" growth rates of $7 \%$ that should be a shame. The "open" unemployment rate has stuck to $7 \%$ of labour force and the "disguised" rate, to around $10 \%$. Moreover, at the end of 2001, annalists were expecting another year of tight monetary policy in order to accomplish the inflation target of $3.5 \%$ for 2002. Because of that, real short-term interest rates in 2002 were projected to stay high, at $12 \%$ per year, with direct consequences for the ratio of net public debt to GDP which amounted to $56 \%$ in December 2001. All that in spite of a primary budget surplus of $3.5 \%$ of the GDP per year.

Chart 2: Brazil: Foreign Direct Investment, Current Account Deficit, GDP Growth and Gross Fixed Capital Formation in selected periods (\%)

\begin{tabular}{lcccc}
\hline & $\begin{array}{c}\text { "end of cycle" } \\
1975-80\end{array}$ & $\begin{array}{c}\text { "hyperinflation" } \\
1981-89\end{array}$ & $\begin{array}{c}\text { "opening" } \\
1990-94\end{array}$ & $\begin{array}{c}\text { "stabilization" } \\
1995-2000\end{array}$ \\
\hline GDP real growth rate & 6.9 & 2.4 & 2.3 & 2.5 \\
Fixed Capital Formation/GDP & 22.6 & 21.3 & 19.4 & 19.6 \\
Current Account Deficit/GDP & $(4.4)$ & $(1.7)$ & 0.03 & 4.0 \\
For. Dir. Investment FDI/GDP & 0.9 & 0.6 & 0.2 & 3.0 \\
\hline
\end{tabular}

Fonte: $\mathrm{BCB}$

The point I want to stress here is that the basic correctness of the policy response in the short period (2001) must not blind us of its probable incompleteness and, hence, incorrectness in the medium and long-terms. In other words, an important battle was won by the government but the war was not over and the side effects of the medicine were grave. The kind of macroeconomic management put forward during 2001 is quite suitable for short-term flow imbalances and mild balance sheets weaknesses that clearly were not our case. Nevertheless, our problems of meagre growth rates and periodic currency crisis, under fixed or flexible exchange rates, point to a more serious nature and hence require a broader sort of medicine.

\section{INCONSISTENCIES OF THE MACROECONOMIC REGIME AND ITS CHALLENGES}

The problem with the recent currency crisis can be stated in the following terms. The bulk of the "homework" regarding the liberalisation of the economy, 
privatisation, budgetary policy and exchange rate policy was done in Brazil, if not during the first mandate of president Cardoso at least in the second mandate. As expected, promises abounded throughout the period. I shall refer to just two of them: the recurrent forecast of annual growth rates of output in the range of $4 \%$ to $5 \%$ and the projected expansion of exports to US\$ 100 billion in 2002. Instead of these, since 1994, we have suffered four strong currency crises related to international developments - Mexico, Southeast Asia, Russia and Argentina - and two of our own breeding (1999 and 2002). No doubt that fixed exchange rates and fiscal imbalances helped a lot for some of those crisis to develop. But it is also true that the flexible exchange rate regime and the primary fiscal discipline, brought about since 1999, fell short of expectations that they could protect our interest rate and income and rule these crises out. As we have seen, the real Selic rate of the period 19992001 averaged $12.1 \%$ per year, a figure lower than the corresponding average rate of the fixed exchange rate period, of $22.1 \%$, but still very high with regard to the country's growth rate and international standards. In 2001, the differential between our overnight interest rate and the fed funds rate widened to $16 \%$ in spite of very favourable results on the budget front (Graph 3).

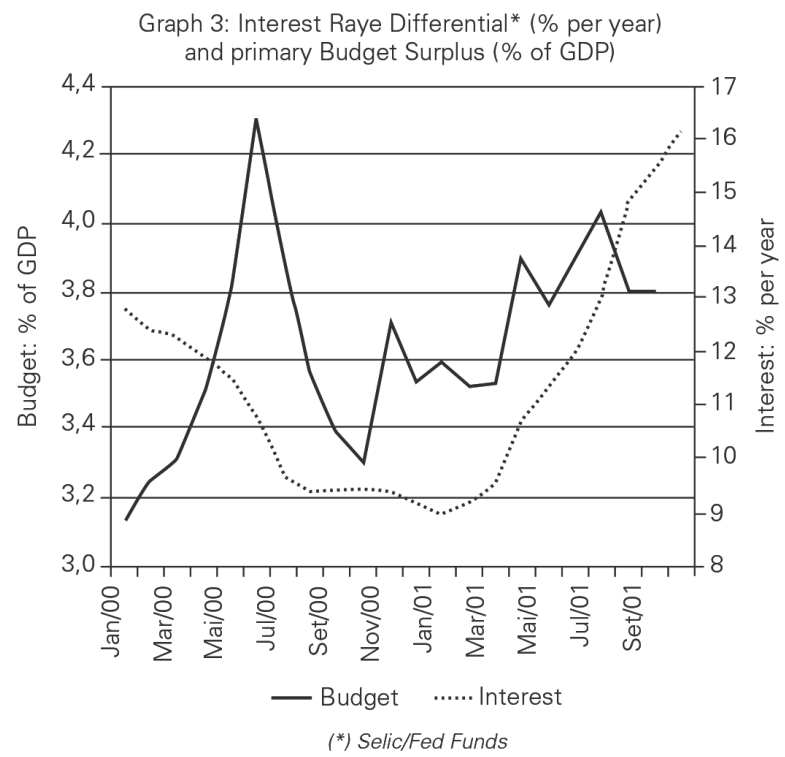

Therefore, something wrong must have happened. The nature of the problem is explained as follows. I quote freely Prof. Dornbusch: "the old-style currency crises involve a cycle of overspending and real appreciation that worsens increasingly the current account leading to demand restraint, trade restrictions and, ultimately, to devaluation. The new-style currency crises involve doubts about the credit worthiness of the balance sheet of a significant part of the economy - private and public - and the exchange rate. Balance sheet issues are fundamentally linked to mismatches; even if there is solvency they still create vulnerability related 
to liquidity problems. Exchange rate depreciation, in a mismatch situation, works in an unstable fashion to increase the prospect of insolvency and hence the urgency of capital flights. A far more dramatic impact on economic activity is to be expected in this case compared to the old style crisis due to the disorganisation effects stemming from illiquidity or bankruptcy. If the exchange rate is fixed, reserves are being depleted and that process increasingly adds currency risk to the equation. If the exchange rate is flexible, depreciation ensues and increasing depreciation is projected. That in turn may spread risk to foreign exchange denominated parts of the balance sheet and aggravate capital flight" ${ }^{3}$.

By and large, this has been our case. Serious flow imbalances with regard to the global budget deficit and to the current account are coupled with substantial balance sheet weaknesses, particularly in the public sector. Maturity and currency mismatches are realities in the private sector, although the primary sector and the banking system have been spared until now. This is why we ended up with the apparent paradox of a "dynamic" economy that does not energise the GDP. Productivity is growing high but so is the interest bill. Regarding balance sheets, it takes two to tango. If debt structure is ugly, it is not enough that the asset side is in good shape.

Therefore, it is clear that we are facing new and graver challenges. Stern macroeconomic management can not be disregarded but to be fully effective it must be linked to more structural policies. I will mention two areas of interest for governmental policies that have been underestimated until now.

First, commercial policy is to be reconsidered. External sector vulnerabilities, albeit diminished, have continued. We had modest trade surpluses for the entire 19952001 period and it remains to be seen if the sizeable surplus expected in 2002 is compatible with a rapid expansion of aggregate demand or is the result of a stagnant economy and bound to be reversed sooner or later. Net capital income sent abroad will probably reach $32.8 \%$ of exports in 2002 , current account deficit decrease sharply in absolute values since the real devaluation but remains high in relation to GDP (around 4\%) and the ratio of net external liabilities to exports stick to a level of 6.0. Exports have grown by an average of only $3.8 \%$ per year since 1994 which compares unfavourably to the effective rate of return on net external liabilities of more than $6 \%$ per year during that period (Chart 3). In short, dependency of Brazilian economy on external capital inflows remains large and is bound to create excess exchange rate volatility in a number of situations.

True, there are some reasons for optimism, considering the improvement of the fiscal stance, the flexible exchange rate regime and the inflow of foreign direct investments. Yet, it should be noted that although they are necessary conditions for exchange rate stability, neither of them has prevented major currency and financial crises elsewhere, as we saw in Mexico, Southeast Asia and Argentina. Therefore, it's not enough that monetary and fiscal policies are geared to price stability and

${ }^{3}$ See Dornbusch (2001). 
Chart 3: Brazilian External Sector Indicators

\begin{tabular}{|c|c|c|c|c|c|c|c|}
\hline & \multirow[t]{2}{*}{ Export } & Capital & Current & Net External & N.E.L./ & \multicolumn{2}{|c|}{ N.E.L. Rate Cap. Incom. } \\
\hline & & Income & Account & Liabilities & Exports & of Return & /Exports \\
\hline & $A$ & B & C & D & $D / A$ & $\mathrm{~B} / \mathrm{Dm}$ & $B / A$ \\
\hline & US\$ bil. & US\$ bil. & US\$ bil. & US\$ bil. & & $\%$ & $\%$ \\
\hline 1994 & 43.5 & 8.5 & 1.7 & 162 & 3.7 & 5.6 & 19.5 \\
\hline 1995 & 46.5 & 10.8 & 18.0 & 168 & 3.6 & 6.5 & 23.2 \\
\hline 1996 & 47.7 & 12.2 & 24.3 & 193 & 4.0 & 6.8 & 25.6 \\
\hline 1997 & 53.0 & 16 & 33.0 & 228 & 4.3 & 7.6 & 30.2 \\
\hline 1998 & 51.1 & 19.1 & 33.6 & 262 & 5.1 & 7.8 & 37.4 \\
\hline 1999 & 48.0 & 19.3 & 25.1 & 287 & 6.0 & 7.0 & 40.2 \\
\hline 2000 & 55.1 & 17.9 & 24.6 & 311 & 5.6 & 6.0 & 32.5 \\
\hline 2001 & 58.2 & 19.9 & 23.2 & 335 & 5.7 & 6.2 & 34.2 \\
\hline $2002 p$ & 56.4 & 18.5 & 16.1 & 351 & 6.2 & 5.4 & 32.8 \\
\hline average 94-02 & 51.1 & 15.8 & 22.2 & 255.1 & 4.9 & 6.5 & 30.6 \\
\hline growth rate $94-02 * *$ & 3.8 & 11.8 & 37.9 & 11.7 & & & \\
\hline
\end{tabular}

Source: BCB and FGV "Conjuntura Econômica". (*) Dm = average net external liability in 2 years (previous and present). $\left({ }^{*}\right)$ average annual growth rate (\%).

the exchange rate to overall balance of payments equilibrium. Sustainability of the current account position is also important and requires additional policies such as commercial policies for export promotion and import substitution in order to bring the current account to more manageable figures. Sometimes, we heard commercial policies could not work in a flexible exchange rate system. This is true for small open economies with perfect capital mobility but the story is completely different in the Brazilian case. On the contrary, particularly in periods of stress, one can assume that the opposite model of no capital mobility at all has been more appropriate to our economy. Therefore, commercial policy can retain its effectiveness ${ }^{4}$.

Secondly, we must address the question of balance sheet weaknesses. Brazil has major weaknesses in terms of its ratio of net external liabilities to exports and its net public debt and a minor one regarding the ratio of short-term foreign debt to international reserves (Chart 4). In contrast to that, we have an undervalued currency and a relatively small ratio of corporate debt to equity that work in our benefit. That is fortunate because it means that we may engage in a process of voluntary, market driven, debt management to pursue a credible restructure with small repercussions in the financial market. This can be done by the gradual exchange of short-term, high interest rate securities and dollar denominated liabilities by longterm liabilities expressed in national money. It is of paramount importance

\footnotetext{
${ }^{4}$ One of the referees complained about the vagueness of this statement. To suit him and others who want more concrete proposals I shall refer to my article "Além da Desvalorização", Política Externa, vol. 10, nº 1, Jun-Aug 2001, pp. 40-56, which deals with this problem.
} 
that, from the beginning, the process receives the aid of multilateral organisations, is backed by a strong fiscal stance and that measures are taken before conditions turn harassing as is the case of Argentina. If low creditworthiness is the main problem, external help is surely part of the solution, both to provide credible collateral and ratify prevailing economic policies.

There are two main obstacles to that initiative: first, multilateral organisations like the IMF, World Bank etc. are not fully prepared to face such challenges. They were built to tackle old type financial crisis that requires much less funding and expertise to be solved. Besides, as it happens with households and firms, governments tend to postpone any movement in the direction of debt restructuring so that leaning against the wind becomes the norm. The consequence is that most of the time when they start it to move it is too late: interest rates are skyrocketing outright recession is established and capital is fleeing the country in huge amounts. Therefore, in this stressful situation, although inevitable, debt restructuring can do little to avoid a collapse let alone to promote a recovery. Fortunately, Brazil is yet in a position to solve its debt problems in a friendly way. The sooner the better.

Chart 4: Selected Countries Critical Indicators 2001 (\%)

\begin{tabular}{lcccc}
\hline & $\begin{array}{c}\text { Corporate } \\
\text { Debt/Equity }\end{array}$ & $\begin{array}{c}\text { Net Public } \\
\text { Debt/GDP }\end{array}$ & $\begin{array}{c}\text { Short-Term } \\
\text { Debt/Reserv. ** }\end{array}$ & $\begin{array}{c}\text { Currenty } \\
\text { Overvaluation*** }\end{array}$ \\
\hline Brazil & 108 & 53 & 69 & 32 \\
Argentina & na & $44^{*}$ & na & -10 \\
Mexico & na & 23 & na & -10 \\
Korea & 518 & -35 & 193 & -24 \\
Malaysia & 150 & na & 41 & -8 \\
\hline
\end{tabular}

$\left(^{*}\right)$ gross debt; $\left(^{* *}\right)$ international; $\left(^{* * *}\right)$ real effective rate, $1995=100,(-)=$ overvalued, na $=$ non available Sources: Dornbusch (2001), OECD and IMF

\section{CONCLUSIONS}

The 2001 Brazilian experience with exchange rate policy in the context of financial and real sectors shocks shows with clarity some not well known facts.

The kind of policy response recommended by the standard theoretical model of flexible exchange rate (Mundell-Fleming) simply does not apply in the case of Brazil. Letting the exchange rate adjust fully to the negative perceptions of risk and augmented expectations of currency depreciation is not an issue in an economy where exposures to currency risks are high. Conversely, fighting this process by sharply raising the key short-term interest rate is no better as more than $50 \%$ of the public debt in bonds and bills is indexed to that rate (Selic). As was argued in the paper, the Brazilian economy operates as if there were some sorts of ceilings for 
the exchange rate and for interest rates, in a clear departure from the assumptions embodied in the "pure" model.

Therefore, any efficient policy response should avoid the extremes of putting much emphasis either on exchange rate depreciation or interest rates hikes and consider also the making of foreign exchange market interventions and the calling in of aid from multilateral organisations whenever the imbalances reach dangerous and, possibly, unsustainable levels. By and large, this was done in 2001 with successful results at least in the short run. Nevertheless, the costs in terms of deteriorating public finances, loss of output and jobs were significant posing a question of whether this kind should be improved or not. Our response was positive and we tried to show that less reliability on foreign exchange interventions and more on interest rate and exchange rate adjustment - i.e., a more balanced approach would probably have provided better results.

We also argue that a better macroeconomic mix is necessary but not sufficient to curb foreign exchange crisis. That happens because Brazil has severe vulnerabilities in three key fronts, the current account, the public finances and the balance sheets. Therefore, periodic exchange rate crisis is a natural outcome as they are incrusted in the whole economic structure. Hence, we need more powerful tools to fight them. Our message is that together with a stronger fiscal stance, more active commercial policies and more creative debt management must be considered if we are to avoid the evils of a financial collapse.

\section{APPENDIX}

I will follow the model presented by Blanchard (2001), pp. 424-434. The goods market equilibrium implies that the output $(\mathrm{Y})$ depends on the interest rate (i), the exchange rate $(\mathrm{e})$ and world demand $\left(\mathrm{Y}^{*}\right)$, given the price level:

$$
\mathrm{Y}=\mathrm{C}(\mathrm{Y})+\mathrm{I}(\mathrm{i})+\mathrm{G}+\mathrm{NX}\left(\mathrm{e}, \mathrm{Y}^{*}, \mathrm{Y}\right)
$$

where $\mathrm{C}$ is consumption, $\mathrm{I}$, investment, G, government expenditures and NX, net exports.

Interest rate is determined by the interplay between real money supply $(\mathrm{M} / \mathrm{P})$ and real money demand (L function). This is the LM curve:

$$
\mathrm{M} / \mathrm{P}=\mathrm{L}(\mathrm{i}, \mathrm{Y})
$$

Interest rate parity between domestic and foreign securities, responsible for balance of payments equilibrium, implies a negative relationship between the spot exchange rate and the domestic interest rate, given the foreign interest rate $\left(\mathrm{i}^{*}\right)$ and the expected future exchange rate $\left(\mathrm{e}^{*}\right)$. This is the BP curve:

$\mathrm{e}=\mathrm{e}^{* /\left(1+\mathrm{i}-\mathrm{i}^{*}\right)}$

Substituting terms, we have the IS curve:

$\mathrm{Y}=\mathrm{C}(\mathrm{Y})+\mathrm{I}(\mathrm{i})+\mathrm{G}+\mathrm{NX}\left[\mathrm{Y}, \mathrm{Y}^{*}, \mathrm{e}^{*} /\left(1+\mathrm{i}-\mathrm{i}^{*}\right)\right]$

The diagram below shows the three curves IS, LM and BP in two graphs. The 
initial equilibrium is at point $\mathrm{E}$, with output at yf, interest rate at i0 and the exchange rate at $\mathrm{e} 0$, given the government expenditures, foreign interest rate, world demand and the real money stock as parameters. In the standard Mundell-Fleming model, a disturbance coming from the external sector, say, an increase in the future expected exchange rate $\left(E^{*}\right)$ or a decrease in foreign interest rate $\left(i^{*}\right)$, leads the economy to a point like J, where output increases to $\mathrm{yd}$, interest rates, to i1 and the exchange rate depreciates (increases) to e1. In terms of policy response, this standard model amounts to a policy of fixed real money supply.

Figure 3

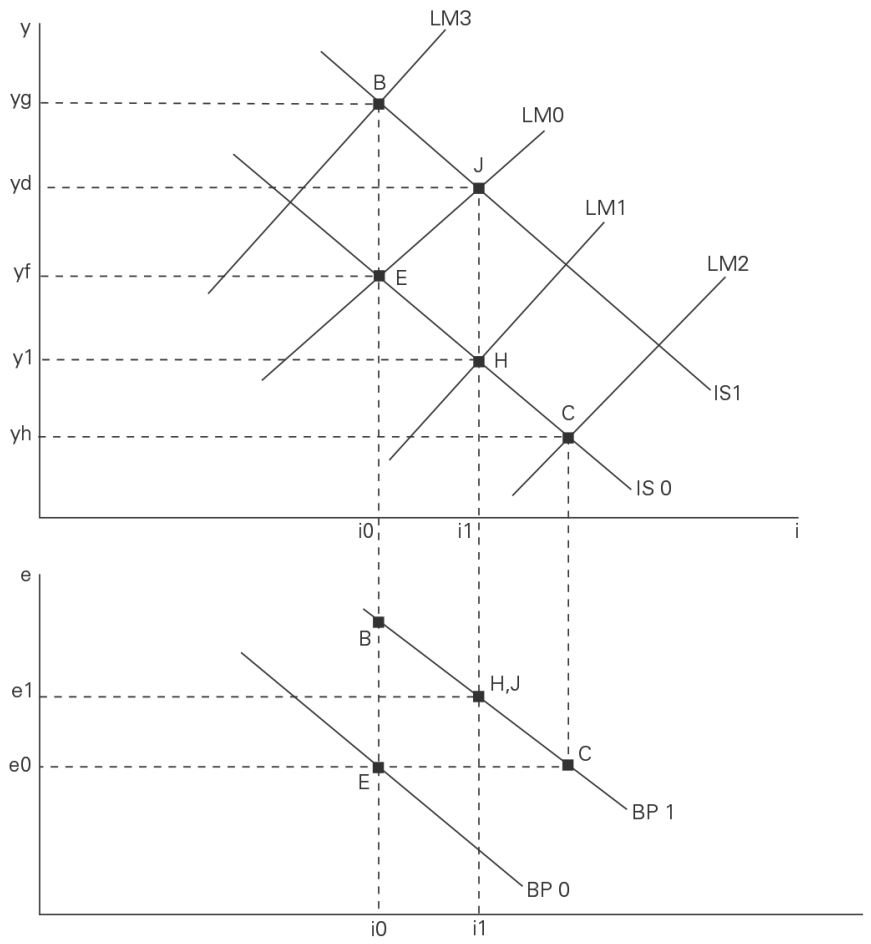

But this is not the case of a developing country with problems of inflation and balance sheets exposure to currency depreciation. A negative result is shown in the figure at a point like $\mathrm{H}$. The LM curve shifts to the right as the central bank tightens monetary policy to either fight inflation or prevent a major devaluation. The real money stock falls. The IS curve stays as it was before the disturbance. Net exports are stimulated by currency devaluation but that is completely offset by a corresponding decrease in investment due to the negative balance sheet effect. At point $\mathrm{H}$, interest rate and the exchange rate go up but output is reduced to $\mathrm{y} 1$.

The policy of sterilised intervention by the sale of international reserve or of dollarised bonds is equivalent to stay at point $\mathrm{E}$, with no devaluation and no interest rate increase. Of course, at this point, below the new balance of payments curve, 
BP 1 , the country is losing reserves continuously so that it can not be a permanent equilibrium. The fixed exchange rate case is equivalent to a point like $\mathrm{C}$, where the central bank fights the currency depreciation by raising sharply its key interest rate and thus reducing the real money stock. The cost is a major recession with output reduced to yh. A policy of fixed interest rate or "clean" float is equivalent to a point like $\mathrm{B}$, where the bulk of adjustment is born by the exchange rate. At this point, monetary equilibrium requires an expansion of the real money supply to the benefit of output which increases more than in the standard Mundell-Fleming model of flexible exchange rate, to yg. Mr. Borensztein's triangle amounts to be the space $\mathrm{ECB}$ in the diagram.

\section{REFERENCES}

BLANCHARD, O. (2001) Macroeconomia, Ed. Campus, Rio de Janeiro.

BORENSZTEIN, E. (2001) “Comments on Lahiri-Veigh's Fighting Currency Depreciation: Intervention or Higher Interest Rates?”, in Preventing Currency Crises in Emerging Markets, Papers and Proceedings of NBER Conference held in January 11-13, 2001.

CAVES, R., FRANKEL, J. and JONES, R. (2001) Economia Internacional, Ed. Saraiva, São Paulo.

DOOLEY, M.(2001) "Responses to Volatile Capital Flows: Controls, Asset-Liability Management, and Architecture", in Capital Flows, Financial Crises and Policies, Papers and Proceedings of World Bank Conference held in April 15-16, 2001.

DORNBUSCH, R. (2001) “A Primer on Emerging Market Crises", in Preventing Currency Crises in Emerging Markets, Papers and Proceedings of NBER Conference held in January 11-13, 2001.

EDWARDS, S., and FRANKEL, J. (2001) "Preventing Currency Crises in Emerging Markets - Introduction", in Papers and Proceedings of the NBER Conference held in January 11-13, 2001.

FARIA, L.(2001) “Além da Desvalorização", Política Externa, vol. 10, n 1, pp. 40-56.

FARIA, L. (2000) “The Transition from Fixed to Flexible Exchange Rates: the Case of Brazil”, ECES Working Papers $n^{\circ} 53$, Cairo.

MONTIEL, P. (2001) "Policy Responses to Volatile Capital Flows", in Capital Flows, Financial Crises and Policies, Papers and Proceedings of World Bank Conference held in April 15-16, 2001.

TARSHIS, L.(1955) International Trade and Finance, John Wiley \& Sons, New York.

WALLICH, H. (1982) Monetary Policy and Practice, Lexington Books, Massachusetts. 